\begin{tabular}{c}
\hline Review of \\
ECONOMICS \\
and \\
INSTITUTIONS
\end{tabular}

\title{
Fiscal Effects of Putting Initiatives on the Ballot: Evidence from the Last 20 Years in the United States
}

\author{
Aline Pennisi \\ Ministry of Economy and Finance (Italy)
}

\author{
Agnese Sacchi ${ }^{\varpi}$ \\ Universitas Mercatorum (Italy) \\ and \\ Governance and Economics \\ Research Network (Spain)
}

\begin{abstract}
In time of worry for large deficits, the question of whether direct democracy is a problem or a promise to better rule modern societies is likely to arise. This paper investigates the effects of both the existence and the use of direct democracy on fiscal outcomes in the United States over the years 1992-2009, by including detailed information on the initiatives which are actually voted. Our results suggest that States permitting initiatives spend less and tax less than those without. However, when initiatives are actually used, their practice contributes to increase spending among those States allowing them. Hence, when passing from existence to usage, the voters' bottomup will reveals an expansionary fiscal trend. This effect occurs when measures are put on the ballot directly by citizens with no role of the State legislature and translates into an increase in general taxation and expenditure consolidated at the State and local level.
\end{abstract}

JEL classification: $\mathrm{H} 71 ; \mathrm{H} 72 ; \mathrm{P} 16 ; \mathrm{O} 51$

Keywords: voter initiatives, fiscal policy, positive constitutional economics, state government

We wish to thank the participants at the XXIV Conference of the Italian Association of Public Economics (held in Pavia, September 2012) and at the European Public Choice Conference (held in Zurich, April 2013) for their comments on a previous version of the paper. Special acknowledgments are due to Antonio Di Majo, Veronica Grembi, John Matsusaka, Andrea Presbitero and Désirée Teobaldelli for their insightful suggestions. We also thank the Editor and an anonymous referee for spotting possible improvements to a previous version of this paper. The views expressed herein are those of the authors and should not be attributed to their respective organisations. The usual disclaimers apply.

$\triangle$ Corresponding Author. Address: Via Appia Pignatelli 62, 00178 Roma (Phone: +3906 78052327, Fax: +39 06 7842136, E-mail: a.sacchi@unimercatorum.it).

\section{Recommended Citation}

Pennisi, A., Sacchi, A. (2014). Fiscal Effects of Putting Initiatives on the Ballot: Evidence from the Last 20 Years in the United States. Review of Economics and Institutions, 5(1), Article 2. doi: 10.5202/rei.v5i1.112. Retrieved from http://www.rei.unipg.it/rei/article/view/112 


\section{Introduction}

As confidence in government decreases and trust in politicians' hits low, the idea of shifting decision-making directly to citizens becomes ever more appealing. Theoretical considerations do not provide a conclusive assessment as to whether institutions of direct democracy have a positive or negative impact on fiscal and policy outcomes. According to some views, direct democracy instruments (e.g., referendums ${ }^{1}$ and initiatives) are influenced by narrow and special interest groups that neglect the majority view (Broder 2000); but to others, they uncover outcomes that are generally supported by the many and affirm that more direct form of democracy may improve productive resource allocation (Blomberg et al. 2004). The central theme of the strand of literature sustaining the "virtuous" effect of direct democracy is based on evidence (basically from the United States and Switzerland) that such instruments increase the flexibility of resource allocation and lead to lower taxes and spending. However, it is not a priori clear whether citizens are generally more in favor of cutting or increasing public spending as this may depend on historical, cultural or other context factors. In time of worry for large deficits and pressure to balance the budget, this raises the question on whether direct democracy can be a problem or a promise to better rule modern societies.

Around half of American States and an increasing number of other countries have adopted some form of direct democracy. 2. The debate about the merits of representative versus direct democracy goes back to ancient times. It is mainly based on the difference between the "people's rule" (i.e. democracy for the Athenians) and the "public thing" (i.e. the choice of a republic for the Romans). In real-world societies of a size too large to efficiently vote directly on all issues, representative and direct democracy are usually complementary institutions; in these societies, a different degree of direct democracy can be combined with representative institutions.

The effects of direct democracy have been explored by many empirical studies, mostly focusing on the US, $]^{3}$ which serves as an interesting labora-

${ }^{1}$ We follow the Oxford English Dictionary and most of the modern literature (e.g., Feld and Matsusaka 2003) in adopting the plural term referendums instead of referenda. See also Butler and Ranney (1994) for further details on this grammatical issue.

2 Recently, Britain has held its first referendum since years (on whether to change its voting system), and the European Union has just introduced the first supranational initiative process. With technology making it ever easier to hold referendums and Western voters ever angrier with their politicians, direct democracy could be on the march. Switzerland is considered, after all, a successful model of direct democracy in the 19th century at the federal level and in the Middle Ages at the local level.

3 US studies range from citizens' voter turnout and civic engagement (Tolbert et al. 2001; Smith and Tolbert 2004) to minority/majority rights (Gerber 1996, 1999; Hajnal et al. 2002), State economic performance (Matsusaka 2005); State and local fiscal policy (Matsusaka 1995, 2004); and the quality of government (Alt and Lassen 2003; Dalton 2008). 
tory thanks to a sufficient variation in types of direct democracy institutions at the State level: more than half of all American States have some form of initiative according to which citizens have the ability to adopt laws or to amend the State constitution.

The issue is widely debated in US in recent history as well ${ }^{4}$ The underlying criticism of the initiative process is that it leads to irrational public policies because voters are myopic that they would approve new spending programs while, at the same time, cut their taxes. However, previous results on the US (e.g., Matsusaka 1995, 2004; Matsusaka and McCarty 2001) prove that State government spending is lower when voters participate directly in policy decisions, i.e. initiative-States spend less than non-initiative ones.

In this study, we are interested in performing a positive analysis on whether direct democracy institutions - considering their existence, usage, types and the topics of concern - have effects on the main expenditure and revenue items at the State level. The existing literature has provided a great deal of descriptive information about voter information, initiative campaigns, and the existence of the initiative process, while it has little to do with the actual usage of direct democracy measures. ${ }^{5}$ Our paper is an attempt to document and disentangle both the effects of initiatives, i.e. one related to their existence and, especially, one related to their practice, with respect to fiscal outcomes and policies across the American States and time. Moreover, it takes into account detailed information on direct democracy measures such as whether direct or indirect initiatives are used and which area of the policy agenda is explicitly involved (e.g., taxes, bonds, education, health, civil rights, regulation, etc.) in order to empirically investigate the effects of these instruments on the main fiscal variables in American States over the period 1992-2009. We follow the suggestion of Blume et al. (2009, p. 454) according to which "[o]ne desirable extension is to divide the category 'initiative' into a number of more fine-grained sub-categories", so we also extend the content of previous works.

To make our study consistent with the standard approach, we start the analysis considering the existence of direct democracy tools (i.e. whether and where initiatives are possible) and we evaluate whether some fiscal effects occur. Then, we focus on the usage of the process (i.e. whether ini-

4 The Economist (April 20th 2011) affirmed that the main culprit of the huge budget hole in California is direct democracy: "[R]ecalls, in which Californians fire elected officials in mid-term; referendums, in which they can reject acts of their legislature; and especially initiatives, in which the voters write their own rules. Since 1978, when Proposition 13 lowered property-tax rates, hundreds of initiatives have been approved on subjects from education to the regulation of chicken coops. This citizen legislature has caused chaos. Many initiatives have either limited taxes or mandated spending, making it even harder to balance the budget".

5 To the best of our knowledge, the only exception is a recent work of Matsusaka (2012), who investigates the importance of quantifying the direct and indirect effects of the initiative, i.e. passed initiatives versus available but not used initiatives. 
tiatives are actually held in practice) so analyzing only the sub-sample of initiative-States in relation to their fiscal performance. Hence, we search for evidence that among initiative-States, the effect of using direct democracy may be different to that of permitting it only. Overall, the dataset refers to a more recent time span with respect to the existing studies, with transparent coding criteria for the institutional and topic details. ${ }^{6}$

Our main results show that States with initiatives spend less and tax less than those without, consistently with previous findings (e.g., Matsusaka 1995, 2004) and extending them to the more recent decade. However, among the States providing for direct democracy legislation, it seems that the actual practice of initiatives plays a different role in affecting fiscal outcomes. Initiative-States tend to produce smaller governments than non-initiative States, but when voters within the initiative-States actually decide to promote an initiative, this tends to expand government intervention. The contradiction in the results between possibility and actual usage of initiatives recalls the distinction between de jure political power - whose allocation is determined by political institutions - and de facto political power - which is possessed by groups to solve the collective action problem (e.g., Acemoglu and Robinson 2006, 2008). In this perspective, it cannot be taken for granted that direct democracy will effectively constrain overspending as voters and their representatives may face the same common pool-disincentives.

More in detail, our findings suggest that voters actually put initiatives on the ballot to favorably influence the fiscal variables they experience more directly. On the revenue-side, this typically leads to a reduction in user fees and charges (which are perceived individually on the basis of each citizen's consumption), while it gives rise to an increase in general taxation (where the individual contribution is harder to disentangle from the collective effort). The former holds when indirect initiatives are at work, while the latter holds when voters circumvent the legislature by using direct initiatives. On the expenditure-side, indirect initiatives shrink State spending, while direct initiatives increase combined State and local expenditures, indicating that voters are more interested in spending for the public goods and services they can see on the ground.

The rest of the paper is organized as follows. Section 2 surveys the empirical literature dealing with the relationship between direct democracy and fiscal outcomes. Section 3 briefly provides background information on voter initiatives in the US, while Section 4 describes the data and the estimation approach here used. Section 5 presents and discusses the empirical results. Finally, Section 6 suggests some concluding remarks and questions

\footnotetext{
6 This was possible thanks to the comprehensive effort conducted by the Initiative $\mathcal{E}$ Referendum Institute (IRI) at the University of Southern California in collecting the data for many years, and additional information tracked on Ballotpedia (which is a free, collaborative, online encyclopedia about State politics, including elections, congress, legislatures, ballot measures, governors, etc.).
} 
for further research.

\section{A Review of the Empirical Literature}

Direct democracy institutions can make politicians more accountable and result in policy choices that more closely match citizen preferences (Voigt 2011). Thus, the use of initiatives (and referendums) should act on government spending making it more in line with citizens' preferences. More precisely, the theory of direct democracy revolves around three main ideas (see Matsusaka 2005): i) the principal-agent problem (where the role of the median-voter is crucial and the effect of direct democracy could be either that of pushing policy closer to the position of the median-voter or that of excluding the median-voter's ideal policy as suggested in Romer and Rosenthal, 1979); ii) asymmetric information (where the performance of direct democracy relative to legislature depends on the nature of the information required to make policy decisions); iii) issue bundling (where direct democracy tools, such as initiatives and referendums, give citizens a way to unbundle specific issues, so avoiding the 'logrolling' phenomenon in omnibus bills).

Each of the above theoretical assumptions provides interesting insights on whether (and when) direct democracy mechanisms are likely to be helpful or harmful for a country's financial balance and inspires empirical investigations. Consistently with the scope of the paper, we focus on a group of studies investigating the impact of the direct democracy process on fiscal outcomes in the US first, and then in other countries In general, most of the literature assumes that there should be some effect in terms of taxes, expenditure and deficits, although the direction of such effect is unclear.

A common feature of studies investigating the impact of the direct democracy process on fiscal outcomes in the US is that only part of the available data is used. Almost all consider the existence and, more rarely, the ease of usage of the initiative process - i.e. State-with versus State-without initiatives - so neglecting the more articulated differences among various instruments of direct democracy (e.g., direct and indirect initiatives). Likewise, the topic or scope for which initiative is undertaken is often not explored even though it can vary hugely. Indeed, initiatives may concern financing single infrastructure projects, welfare policies, taxation, state spending and bonds, electoral issues, environmental and regulation institutions, civil rights, etc. We try to address these omissions.

As for the results, a common finding of more than ten studies (listed in Matsusaka 2004) is that, all other things equal, initiative States tax and spend less than non-initiative ones, at least from the mid-1970s to the end1990s. The "full" initiative effect is considered (see Gerber 1999), in the sense that no distinction is made between measures inserted on the ballot by the voters, with no direct involvement of their representatives through the leg- 
islature (known as "direct initiatives") and measures inserted on the ballot by legislation (known as "indirect initiatives"). Actually, this distinction is relevant as it pertains to two different types of initiatives that are characterized by a different intensity of how "direct" democracy actually is.

More generally, for empirical purposes the initiative effect cannot be measured solely by examining the propositions that actually pass (Lupia and Matsusaka 2004), but it should also try to consider information on both how difficult it is to use direct democracy instruments and what kind of issues are at stake. In this line, Matsusaka (2012) proves that both direct (i.e. initiatives change policy directly through voters approving laws that override the legislature) and indirect (i.e. the initiative process represents a threat that induces the legislature to change policy) effects are important in the US, but the direct effect is several times more important than the "threat effect".

As for the US, beyond the findings of lower spending in initiative-States than in those without, there are some cases showing the opposite trend. Among others, Zax (1989) found that direct democracy institutions increased per capita government spending in 1980 for 50 American States and 1,305 local communities; Marschall and Ruhil (2005) demonstrated that ignoring States' voluntary adoption of direct democracy when analyzing fiscal outputs generate biased and unreliable estimates of initiative effects, and that the initiative actually increased State expenditures, revenues and taxes over the period 1960-2000. Hence, in these studies, rather than reducing the size of the public sector, the initiative appears to have fostered and expanded the fiscal role of State government.

This pattern is actually quite similar to the one observed by Zimmerman (1999) and Matsusaka (2000) over the previous period (between 1900 and 1940), wherein initiative-States were more likely to require increases than decreases in expenditure (especially for education and welfare categories). The positive relationship between initiatives and public spending can be explained by the fact that if the initiative makes policy more responsive to public opinion, it is easy to note that, more often than not, public opinion calls for more government expenditure - as it seems to be happened from 1960 to 2000 in the US (Marschall and Ruhil 2005).

Another shared result is that neither initiatives nor referendums seem to have a significant effect on the amount of debt issued. Similar evidence for the US is provided by Matsusaka (1995, 2004) and Bohn and Inman (1996), wherein States with initiatives are no more likely to borrow than those without initiatives. Finally, Camobreco (1998) found that initiatives have no effect on state and local (combined) per capita expenditures and tax effort in 1988 and 1990. Hence, the evidence on the net policy impact of the initiative in the US is rather mixed (for an historical perspective see Smith 2001).

Overall, as suggested by Lupia and Matsusaka (2004), the conclusion may be that rather than thinking of direct democracy as ideologically pre- 
disposed in a particular direction - i.e. increasing or decreasing public spending - one should think of it as a "median-reverting" institution, which pushes policy back toward the center when legislatures move too far to the right or left.

With regard to countries other than the US, Feld and Matsusaka (2003) deal with the effects of mandatory fiscal referendums in 26 Swiss cantons from 1980 to 1998 and find that cantons with such mechanisms spend significantly less (about 19\%) in per capita terms than cantons without them, holding constant other determinants of spending such as income. They also document an interaction between the mandatory referendum and voter initiative suggesting that the initiative process is a substitute way to restrain government spending ${ }^{7}$ On the other hand, Hinnerich and PetterssonLidbom (2010) find that in the Swedish context going from a direct democracy (in the form of local town meetings) to a representative system dramatically increases political participation and redistributive spending towards the poor (in the form of poverty relief, child welfare and basic public education programs), possibly due to the fact that direct democracy is more prone to capture by (rich) local elites than representative democracy.

Keeping a comparative perspective, Blume et al. (2009) propose the first cross-country study analyzing the economic effects of direct democracy in 88 countries over the period 1996-2005 with findings only partially confirming prior intra-country results. Indeed, they show that total spending (as well as that on welfare) is lower in countries with mandatory referendums but, at the same time, that countries with national initiatives appear to spend more and be more corrupt.

Finally, studies on the fiscal effects of direct democracy are also devoted to analyze whether this process affects the vertical structure of government. Some recent examples are provided for Swiss cantons by Funk and Gathmann (2011), and Galletta and Jametti (2012) and German local governments by Asatryan et al. (2013). The former estimate the impact of direct democracy on government spending by using historical data and find that it constraints canton spending with, however, more modest effects than those previously obtained by other cross-sectional studies (e.g., PetterssonLidbom and Tyrefors 2007). The Galletta and Jametti (2012) explore how the vertical structure of direct democracy in a federal context affects expenditure decisions of sub-central governments and highlight that municipalities without fiscal referendums, but belonging to cantons with fiscal referendums, present higher expenditure. Finally, Asatryan et al. (2013) show that direct democracy had a significantly positive and robust effect on local government spending and revenue, diverging from the Swiss or US experience, probably due to the fact that cooperative form of federalism in Germany

7 Likewise, Feld and Kirchgässner (2001) find that in Swiss cantons with the mandatory referendum, both expenditure and revenue are lower by about $7 \%$ to $11 \%$ compared to cantons without mandatory referendums. 
results in strong common-pool disincentives on part of local voters.

More generally, our paper contributes to the wider discussion on the link between democracy and fiscal policy. A relevant strand of literature focuses on representative democracy, identifying the relationship between specific electoral systems or constitutional arrangements and fiscal outcomes. Persson and Tabellini (2004), for instance, analyze the effect of electoral and constitutional rules on the size and composition of government spending in a sample of 80 democracies over the period 1990-1998, finding that presidential regimes induce smaller governments than parliamentary democracies, while a switch from proportional to majoritarian elections leads to smaller total government spending and smaller welfare programs as well. These effects are particularly pronounced in better and older democracies. Cheibub (2006), with on data for democracies in 98 countries between 1970 and 2002, shows that the GDP-ratio of the central government budget balance is higher in presidential than in parliamentary democracies and suggests that this is due to the "costs of coalition" that allegedly afflict parliamentary democracies but rather the higher incentives for governments to keep budgets under control when there is president to vote for. Likewise, Iversen and Soskice (2006) test a model on post-war data for redistribution and its relationship with government partisanship and electoral institutions in advanced democracies, proving that multiple veto points reduce redistributive spending, while proportional systems have a direct positive effect on government redistribution.

Although in slightly from a different viewpoint, Hessami et al. (2012) analyze the interplay of democracy and corruption as determinants of the composition of redistributive transfers for 34 OECD economies over the 1984-2007 period. They find robust evidence in favour of a positive correlation between in-kind spending and perceived corruption in the "most democratic" OECD countries and in those more populated by free media and other specific institutional characteristics that normally further enhance democratic accountability. Following these lines of research, we provide further insights on how direct democratic institutions can further change fiscal behaviours in countries that already have a representative democracy.

\section{Direct Democracy Measures in the United States: Characteristics and Trends}

The foremost example of direct democracy in the US is the use and development of initiatives and referendums,,$^{8}$ whereby "the initiative is the means by which voters can correct legislative sins of omission and the pop-

8 A third variant are plebiscites, often used by the governing class to have its policies confirmed. They usually do not have a binding effect, which is why they do not play an important role in the literature on the economic and fiscal effects of direct democracy. 
ular referendum as the means of correcting legislative sins of commission" (Magelby 1984). The use of referendums can be prescribed by the constitution for passing certain types of legislation: in this case, agenda-setting power remains with parliament, even though citizens' consent is required, ${ }^{9}$ but their use is less frequent than initiatives.

We focus on initiatives only as the best instrument to capture the degree of direct democracy in the US. Initiatives allow citizens to become agenda setters as they can directly adopt laws or amend the State constitution. More precisely, the standard form of an initiative permits citizens to propose a new law that can be placed on a statewide ballot (under the condition that a predetermined number of signatures from fellow citizens is collected) and approved or not by voters through a majority rule; if there is the approval, the proposal becomes law.

A direct initiative is one for which citizens' proposals are directly placed on the election ballot and then submitted to the people for their approval/rejection, without any role of State legislature in this process; an indirect initiative is, instead, a proposal promoted by citizens but subject to the preliminary approval of the State legislature during a regular legislative session. Hence, the main difference concerns the degree of direct democracy entailed by the two measures. We also take into account this difference in the empirical analysis.

In the US, there is no a federal initiative process but in 2011 around half of the American States had initiatives (either direct or indirect) ${ }^{10}$ and the use of initiatives has expanded tremendously in the past century. In particular, the IRI calculates that there were 118 statewide initiatives in the US during the 1950s; this figure increased to 378 initiatives in the 1990s, and remained quite stable for the decade 2000-2009 (367 initiatives) ${ }^{11}$ In the period covered by our study, from 1992 to 2009, we count 1,002 initiatives put on the ballot (650 direct and 352 indirect), of which about 53\% passed. Figure A.1 (see the Appendix) shows the total number of initiatives (including those passed and failed) for each State over our time span. The most frequent usage is observed in California (143), followed by Oregon (119).

Details on how the initiative is administered vary across States as concerns the following features: the number of signatures needed and their

\footnotetext{
9 Referendums can be popular or legislative according to the actor who "starts" the mechanism. In the first case, citizens have the power to refer to enacted specific legislation for the people to either accept or reject; in the second case, an elected official, a constitutional commission, the state legislature or other government/department agency submits propositions to the people for their rejection or approval.

${ }^{10}$ States having the initiative process are: Alaska, Arizona, Arkansans, California, Colorado, Florida, Idaho, Illinois, Maine, Massachusetts, Michigan, Missouri, Mississippi, Montana, Nebraska, Nevada, North Dakota, Ohio, Oklahoma, Oregon, South Dakota, Utah, Washington, Wyoming.

${ }^{11}$ A similar trend apparently occurred at the local level, as citizens and interest groups increasingly turned to direct democracy to advocate their positions. In addition, about half of all cities also provided for the initiative.
} 
deadline and their geographic distribution; the presence of single or more subjects on the ballot; the circulation period; the final approval and other minor points. Finally, initiatives can aim at different levels of legislation (constitutional versus ordinary legislation), and their scope can vary hugely (e.g., some constitutions prohibit initiatives on budget-relevant issues). In 2009 (the latest data available in our sample), for example, headline issues were gay rights, tax and expenditure limits; likewise, in 2008 issues concerning civil and social rights represented the leitmotiv of ballot propositions combined with tax and expenditure measures, while in 2007 it is more difficult to identify a common trend given relatively few measures on the ballot (even though taxes and bonds are often favourite topics).

\section{The Empirical Analysis}

The fiscal effects related to the existence of direct democracy institutions and those related to actually putting initiatives on the ballot are analyzed separately. The former is more conventional in the literature and we start from this approach consistently with previous studies - especially on the US; the latter represents a novelty and requires more information on the effective implementation of voter initiatives within each State year-by-year.

As a matter of fact, a State may allow initiative institutions, but it may not use them in practice for many years. In our sample, some notable examples are Illinois and Mississippi that allow initiatives, but have actually used them only few times in the last 20 years. In this perspective, the existence of direct democracy institutions is not a sufficient condition to denote the effective usage of them and different fiscal effects may also arise. As affirmed by Bowler and Donovan (2004), although many analysts treat the initiative process as one that is essentially similar across states that permit it, there is, in fact, a great deal of variation in the implementation of the process across the US. Modeling the initiative process on the basis of the sole institution may misrepresent the actual phenomenon by lumping together states that make active and repeated use of the process and those that do not.

\subsection{Existence}

The unit of observation of the this part of the analysis is each American State, excluding Alaska, ${ }_{12}^{12}(i=1, \ldots, 49)$ over the $1992-2009$ period. Hence, we have a strongly balanced panel based on annual data for a total of 882 observations. The "existence" benchmark specification is the following:

\footnotetext{
${ }^{12}$ Alaska is not included in our estimations as it is a significant spending/revenue outlier (due to oil severance taxes) as well as an initiative-State. Thus, including it alone can create a positive connection between spending and direct democracy, also because of the lack of good controls for oil revenue among our right-hand side variables, and distort the findings. Previous works on the US adopt the same correction (e.g., Matsusaka 1995).
} 


$$
\text { Fiscal_item }_{i t}=\alpha+\beta \text { Existence_dd } d_{i t}+\sum_{k=1}^{n} \gamma_{k} \text { Control }_{k, i t}+v_{t}+\varepsilon_{i t}
$$

where Fiscal_item $_{i t}$ denotes the dependent variable representing the main fiscal items (e.g., general revenue; taxes; charges; general expenditure) expressed in per capita current dollars and used one at a time. The dependent variables are described more in depth in Section 4.3.

On the right-hand side of equation (1), Existence_dd $d_{i t}$ stands for a dummy variable indicating whether or not a State provides legislation allowing for voter initiatives (i.e. dummy $=1$ if State permits initiatives; 0 otherwise). This proxy for direct democracy - which is time-invariant - is traditionally referred to in the literature and captures only the existence of the initiative process neglecting, instead, its actual usage. In this respect, the existencedecision sounds as a top-down handout, while the usage-decision mostly captures a bottom-up will. The initiative status was established in most States many decades before the sample period, so we can assume that the decision to adopt them is, in practice, exogenous to policy decisions made in the sample period - as do in most previous studies (e.g., Matsusaka 1995, 2004; Lascher et al. 1996; Bowler and Donovan 2002).13 Given that States' decisions on whether to contemplate these institutions are very far in time (several decades before the period of this study), they can be considered exogenous to the fiscal variables under investigation.

By estimating the effect of direct democracy existence on the main fiscal variables, we also control for other socio-economic factors that may affect State fiscal policy, making our study consistent with the conventional approach (e.g., Matsusaka 1995). The set of controls $\left(\right.$ Control $\left._{k, i t}\right)$ includes demographics variables at the State level such as: population density $(P O P-$ $D E N S$ ) in order to capture the presence of economies of scale in providing government services; the annual growth rate of population (POPGROWTH), which is expected to lead to a short-run demand for public spending that usually requires, in turn, some form of taxation; the percentage of population with total full- and part-time employment by industry (INDUS$T R Y(P O P)$ to control for potential differences between more and less developed area in benefits of spending and costs of rising revenue.

In addition to demographic variables, income per capita (INCOME PC) is included among the covariates as it represents a predictor of government

\footnotetext{
13 To our knowledge, a notable exception is the work of Marschall and Ruhil (2005), who explicitly address the potential endogeneity of the initiative, even considering combined state and local spending and taxation. Moreover, Funk and Gathmann (2011) also deal with the bias from observed feedback effects between spending trends and the strength of direct democracy in a Swiss canton. In their case, this choice is supported by the fact that they consider a time span of about 100 years during which a number of substantial changes in direct democracy institutions took place and they should be carefully examined.
} 
size and public expenditure in the long run and it has a natural relationship with the revenue side. Federal revenue transfers to States (FEDERALREV) belong to the controls of equation (1) as they can play a role in affecting States' fiscal decisions concerning both sides of the budget and, at the same time, they can be assumed exogenous with respect to such decisions. ${ }^{14}$ Finally, year dummies $\left(v_{t}\right)$ are used to control for federal shocks that may affect more than one State at the same time, while $\varepsilon_{i t}$ is the standard error term. To get heteroskedasticity and autocorrelation (up to some lag) consistent standard errors, we use the Newey-West estimator with lag length one after observing the residuals correlation over time (results are consistent by increasing the lag-structure up to three lags). 15

\subsection{Usage}

When analyzing the effects of using direct democracy tools, we focus our attention only on initiative-States (i.e. those that actually allow initiatives) and analyze what happens on fiscal outcomes when initiatives are actually held. Hence, the unit of observation of the second part of the analysis is each initiative-State, always excluding Alaska $(i=1, \ldots, 23)$, during the same time period $(t=1992, \ldots, 2009)$. The panel remains strongly balanced with 391 observations due to a fewer number of States and the use of a one-year lagged model. The general "usage" specification is the following:

$$
\text { Fiscal_item }_{i t}=\alpha_{i}+\sum_{j=1}^{s} \beta_{j} U_{\text {sage_d }} d d_{j, i t-1}+\sum_{k=1}^{n} \gamma_{k} \text { Control }_{k, i t}+v_{t}+\varepsilon_{i t} \text {. }
$$

On the left-hand side of equation (2), the dependent variables are the same as those used in equation (1). On the right-hand side, instead, we introduce a variable, Usage_d $d_{i t-1}$, which stands for the year-by-year usage of different measures of direct democracy. Passing from more general to more analytical exploration, we develop three specifications of this model. First,

\footnotetext{
${ }^{14}$ For States, amounts received directly from the federal government includes federal grants and aid, payments-in-lieu-of-taxes on federal property, reimbursements for State activities, and revenue received but later transmitted through the State to local governments. Even if federal aid is endogenous, its inclusion does not bias estimates as block grants, general revenue sharing and also categorical grants and matching funds are awarded on the basis of formulas set by federal officials (e.g., Congress or administrators), so reflecting political bargaining at the federal level (Matsusaka 1995). As a result, a State's ability to increase its fiscal aid by altering its fiscal behavior may be small (see also Hale and Palley 1981).

${ }^{15}$ Given the persistence of the dependent variable, the error term is likely to be serially correlated. The Newey-West estimator (1987) with lag length zero is identical to the White estimator. Although Newey-West standard errors have initially been proposed for use with time-series data only, panel versions are also available. Robustness checks are performed by using Fixed-Effect panel estimator with robust standard errors (estimations are not reported in the paper but available upon request).
} 
we consider the general question related to any initiative actually occurring; then we check on the impacts of different types of initiatives being held (direct or indirect). When analyzing the types of initiative, we also consider the percentage of those which were successful, i.e. passed with a majority of votes. Finally, we look into which policy topics are being addressed when actually putting the initiatives on the ballot (grouping them according to six different major policy categories). Details of all these measures are reported in the next section before discussing the results. In all cases, a dummy variable indicates whether an initiative has actually taken place considering these three cases: in general; for each type; for each topic.

With respect to the existing literature, focusing on whether an initiative was held or not in a given year and in a given State, rather than on the mere existence of institutional frameworks allowing for initiatives to take place, is a novelty ${ }^{16}$ Indeed, we are able to exploit not only the variation in direct democracy legislation but the actual usage of initiative measures.

Even though several initiatives might be held by the same State in the same year (as described in Section 3), counting their frequency does not necessarily lead to a straightforward indicator of intensity, thus leading us to prefer a dummy variable instead, consistently with other studies focusing on direct democracy practice beyond its existence (e.g., Asatryan et al. 2013). Moreover, one same initiative might contain one or more propositions and questions, and initiative ballots tend to feature more measures in general election years than in the others, making an equal comparison difficult. Finally, some States place a limit on the number of initiatives which can be submitted to the voters at any one election.

In each of the three specifications of equation (2), the direct democracy usage-variable is lagged by one year. It makes sense that fiscal effects - if any - will not occur in the same year initiatives are held but, reasonably, later on; furthermore, voter initiatives mostly take place at the end of the year, in November (coupled with general elections). Hence, our benchmark specification is based on a different time-unit for fiscal outcomes respect to direct democracy events in order to take into account the not-instantaneous effects of initiatives.

This strategy also contributes to avoid potential reverse causality problems between fiscal outcomes and initiative usage, allowing for a time lag between them. It might not be enough to guarantee causal inference, as some initiatives could be the response to emerging problems in fiscal policy. However, most initiatives in our time period do not strictly refer to fiscal variables, but to broader society arrangements (e.g., same sex marriage, adoption, decriminalizing marijuana, hunting, environment regula-

\footnotetext{
${ }^{16}$ In fact, to the best of our knowledge, the only exception is the study by Asatryan et al. (2013), who also focus on the actual usage of direct democratic tools rather than on the institutional features alone. Like us, they use a dummy variable indicating whether an initiative/referendum has taken place in a given state/town and year.
} 
tion, property rights, and legislature mechanisms) that more probably have an effect on revenues and expenditures only in the very long run ${ }^{17}$

The rest of the right-hand side variables are the same as equation (1), with the exception of state-fixed effects $\left(\alpha_{i}\right)$ that are here added to control for State-specific time-invariant variables. As before, each regression is estimated through the Newey-West estimator (with lag length one) allowing standard errors that are robust to heteroskedasticity and autocorrelation. ${ }^{18}$ Summary statistics on explanatory and controls variables of equations (1) and (2) are reported in Table A.1 (see the Appendix). Demographic and employment data come from the Regional Economic Accounts provided by the US Bureau of Economic Analysis (BEA); detailed data and qualitative information on direct democracy measures are derived from the Initiative $\mathcal{E}$ Referendum Institute (IRI).

\subsection{The Dependent Variables.}

We essentially look into fiscal and economic data referring to the State government sector. There are several reasons for focusing our analysis mainly on the State level. State-wide initiative measures sometimes concern expenditures and revenues handled by local governments, ${ }^{19}$ but the majority of spending functions is allocated at the State level and their general expenditure also includes intergovernmental resources from States to lower tiers of government (mainly local units and districts). Likewise, most taxes (basically sales taxes, VAT and tax base sharing for income) are decided and administered by each State. Moreover, States have a higher degree of autonomy on tax/expenditure decisions than local governments, whose finance basically depends on intergovernmental grants. Finally, the organization of the local government sector is at the discretion of the States and the structure of lower tiers is quite different across States, making difficult to provide a general framework concerning the functions of the various forms of local authorities 20

${ }^{17}$ We analyze the correlations between the main fiscal variables and the number of initiatives held State-by-State finding low values (i.e. under 0.2) for all fiscal items even when four-year averages are considered.

18 Robustness checks are performed by using FE panel estimator with robust standard errors (estimations are not reported in the paper but available upon request).

${ }^{19}$ For example, California's Proposition 98 in 1988 requiring the State to provide specified minimum levels of spending for schools districts, and California's famous Proposition 13 in 1978 cutting local property taxes.

${ }^{20}$ Even though conceptually it makes sense to look for the effect of statewide initiatives on combined State and local spending, it may be more interesting to investigate how the cuts and increases in the overall government size were achieved, i.e. whether they come from State governments or local governments or both. This approach is followed by Matsusaka (2004) when he deals with the question of whether initiatives have any effect on the distribution of government spending between the State and the local level, finding that initiative-States spend 13\% less per capita at the State level than non-initiative ones, but they also spend $4 \%$ more on the local level. Additionally, the effect of the initiative 
As for the initiative process, it is worth noting that in many towns and cities local initiatives actually exist, and they usually allow voters to propose charter amendments or municipal ordinances. However, our dataset does not include this kind of information that could basically affect local fiscal patterns but that is unlikely to impact on the State level. ${ }^{21}$ More importantly, constitutional limitations from the State level exist and they confine initiatives (and referendums) to the authority of the legislative branch of State government. It follows that: i) on the local level initiatives and referendums are confined to State grants of power to local legislative bodies; ii) courts rely on to limit direct democracy concerns resolutions and ordinances in local government, then initiatives may address only those areas subject to regulation by ordinance; iii) local initiatives (or referendums) are invalid if they relate to statewide affairs (for further details see Olson 1972 and Gunn 1981).

On the other hand, given that there are statewide initiatives that may impact on local expenditures, we do analyze combined State and local fiscal outcomes to provide additional information and as robustness test (see Section 5.5).

In detail, the fiscal items considered as dependent variables are general State expenditure, general revenues, taxes and charges (i.e. Fiscal_item ${ }_{i t}$ ). We start with general expenditure, which includes direct general expenditure (comprising basically the payment of salaries, retirements of former employees, current operations, capital outlay, debt interests, subsidies and assistance) and intergovernmental expenditure (representing the grants, shared taxes, contingent loans and advances, and any significant and identifiable amounts or reimbursement paid to other governments in exchange for specific services or activities), so to avoid underestimating the role of State government in spending decisions even outside the functions it performs directly. ${ }^{22}$

The revenue side is also explored as dependent variable in equations (1) and (2) to analyze how direct democracy institutions affect the way in which expenditures are financed. In this perspective, we consider three main items: i) general revenues (net of intergovernmental revenue); ii) taxes; iii) charges. ${ }^{23}$ More precisely, we consider general revenues basically from

on State spending is more "dramatic" than one for combined "State plus local" spending ( $4 \%$ less) over the same period, suggesting that such institutional tool may be more important for the spending composition rather than for its level.

${ }^{21}$ In the largest cities, initiatives and referendums are actually the rule, not the exception. However, provisions for initiatives and referendums vary considerably across cities and, in some cases, only a restricted amount of topics can be addressed. For example, New York limits initiatives to charter amendments that pertain to the "manner of voting" or those that abolish or create offices. San Antonio and Detroit do not allow initiatives to appropriate money or to levy taxes. For a more extensive review, see Matsusaka (2003).

22 The money raised by the State, and then transferred to a local government showing up as a local expenditure, is included in the first aggregate.

${ }^{23}$ General revenue is all government revenue except utility, liquor store, and insurance 
"own sources", say revenues in the form of taxes or charges but not coming from the federal government; the latter are, instead, used as control variable in both equations.

Descriptive statistics of all dependent variables - used one at a time in the empirical analyses - are reported in Table A.2 in the Appendix. Fiscal, economic and financial data are derived from the Annual Survey of State Government provided by the US Census Bureau.

\section{Results and Discussion}

Results are grouped into different cases referring to the effects of both direct democracy existence from equation (1) and direct democracy usage from equation (2) on fiscal items. We start by presenting results related to the variable Existence_d $d d_{i t}$ for each dependent variable on a whole sample of the American States. Then, we show results related to the Usage_dd $d_{i t-1}$ variable, considering its three main dimensions: the general usage of initiatives; the usage of initiatives by type; the usage of initiatives by topic. The $U$ sage_d $d d_{i t-1}$ specifications are referred to the sub-sample of initiative-States only. Finally, we provide some robustness checks using State and local fiscal aggregates. Each case is treated and discussed separately in the next sessions.

\subsection{The Existence of Direct Democracy}

Table 1 shows estimation results from equation (1), where each column is a regression referred to a specific fiscal item and the variable Existence_dd $d_{i t}$ is a dummy equal to 1 if State permits initiatives in year $t$. In all regressions, we observe that the coefficient on the initiative dummy variable is almost always statistically significant at the conventional level across specifications and its negative sign indicates that, on average, initiative-States spend and tax less than representative States over the whole period. Overall, these results confirm the common finding of many studies on the US (see Matsusaka 2004 for a review). ${ }^{24}$

Moreover, the magnitude of the coefficients is lower for the expenditure

trust revenue; we voluntary exclude intergovernmental revenues (mainly from the federal government) from this definition. Taxes are compulsory contributions exacted by a State government for public purposes, other than for employee and employer assessments and contributions to finance retirement and social insurance trust systems and for special assessments to pay capital improvements. It consists of all taxes imposed by State (e.g., property tax, sales tax, and income tax revenues). It excludes charges for services and revenues from utilities and liquor stores. Charges are revenue received from the public for performance of specific services and from sales of commodities and services, expect liquor store sales. This includes fees, assessments, and other reimbursements for services, rents, etc.

24 These results are confirmed when combined State and local expenditure or revenue is taken as dependent variable (not reported in the paper). 
Table 1 - The Existence of Direct Democracy

\begin{tabular}{|c|c|c|c|c|}
\hline Variables & $\begin{array}{c}\text { General } \\
\text { Expenditure }\end{array}$ & $\begin{array}{c}\text { General Revenue } \\
\text { (net of intergov. revenue) }\end{array}$ & Taxes & Charges \\
\hline \multirow[t]{2}{*}{ Existence_dd $t$} & $-90.0 *$ & $-104 * *$ & -48.8 & $-55.5 * *$ \\
\hline & $(51.0)$ & $(44.9)$ & (34.8) & $(22.0)$ \\
\hline \multirow[t]{2}{*}{ INCOME_PC } & $0.75 * * *$ & $0.60 * * *$ & $0.43 * * *$ & $0.17 * * *$ \\
\hline & $(0.073)$ & $(0.062)$ & $(0.046)$ & (0.039) \\
\hline \multirow[t]{2}{*}{ FEDERALREV } & $1.13^{* * *}$ & $0.38 * * *$ & $0.20 * * *$ & $0.18^{* * *}$ \\
\hline & $(0.094)$ & $(0.067)$ & $(0.056)$ & $(0.037)$ \\
\hline \multirow[t]{2}{*}{ POPGROWTH } & $-89.3 * * *$ & $-39.9 * *$ & -8.76 & $-31.1 * * *$ \\
\hline & $(28.7)$ & $(20.1)$ & $(16.7)$ & (10.6) \\
\hline \multirow[t]{2}{*}{ POPDENS } & $1.10 * * *$ & $0.85 * * *$ & $0.73 * * *$ & $0.12 * *$ \\
\hline & $(0.13)$ & $(0.11)$ & (0.089) & $(0.051)$ \\
\hline \multirow[t]{2}{*}{ INDUSTRY_POP } & 5.23 & $26.3 * * *$ & $15.5 * * *$ & $10.9 * * *$ \\
\hline & $(5.53)$ & $(5.22)$ & $(4.22)$ & $(2.39)$ \\
\hline \multirow[t]{2}{*}{ Constant } & 82.9 & $-1,261 * * *$ & $-710 * * *$ & $-551 * * *$ \\
\hline & (328) & (283) & $(226)$ & (133) \\
\hline State dummies & No & No & No & No \\
\hline Year dummies & Yes & Yes & Yes & Yes \\
\hline Observations & 882 & 882 & 882 & 882 \\
\hline Number of States & 49 & 49 & 49 & 49 \\
\hline F test & 0.000 & 0.000 & 0.000 & 0.000 \\
\hline
\end{tabular}

Significance level: ${ }^{* * *} p<0.01,{ }^{* *} p<0.0{ }^{*} p<0.10$.

Note: The dependent variables are expressed in per capita current dollars. The data are pooled from 1992 to 2009 (Alaska is excluded from all regressions). Coefficients on year dummies are not reported in the table. Newey-West (1987) robust standard errors (assuming a one-lag autocorrelation structure of the error term) are in parentheses. Source: Authors' elaborations 
regression than for those related to revenue items. Considering the revenue side, it seems that permitting initiatives has an effect on the tax mix: overall initiative-States raise less general revenue, all other things equal, but while they collect less revenue from charges than non-initiative-States, no relevant effects emerge for taxes (i.e. the initiative coefficient is not statistically significant). Hence, the possibility of initiatives is likely to alter the way in which funds are raised: broad-based taxes are not affected, while user fees and charges for public services decrease. The reason why voters may prefer to decrease charges than taxes through the initiative mechanism is that they can better perceive the link between expenditure and revenue decisions when charges are used, instead of taxes, as there is a higher correspondence between those who benefit from government spending and those who pay for it.

As for the controls, income per capita (INCOME PC) is positive and highly statistically significant in all specifications: income is, as expected, the most important driver of general expenditure and it also has a strong relationship with general revenues and taxes, recalling that direct democracy is not the key element in shaping fiscal policy. The same holds for the percentage of population working full- and part-time by industry (INDUSTRY POP) and for federal aid (FEDERALREV) across different specifications. Among the demographic variables, population growth (POPGROWTH) and population density (POPDENS) tend to work in opposite directions, while the year-dummies do explain the variation in each fiscal item over the sample period.

To sum up, allowing the initiative process drives down both taxes and spending. Hence, the view according to which voters are short sighted so voter initiatives would favor tax cuts and, at the same time, increase spending, so forcing the government to borrow until it runs out of credit, is not supported by our findings. Finally, it is worth noting that variables reflecting the presence or absence of initiatives perform well in estimating the adoption of this policy across the 49 States, however this tells us little about how the variation in institutional rules affects the variation in policy. To this purpose, we should pass to the usage analyses.

\subsection{The General Usage of Direct Democracy}

Table 2 reports estimates of equation (2), where each column is a regression referred to the four dependent variables one at a time. The variable $U s a g e_{-} d d_{i t-1}$ is a dummy one-year lagged, which is equal to 1 when an initiative-State has actually used and voted direct or indirect initiatives year-by-year during the period 1992-2009.

Direct democracy practice is statistically significant and positively associated with the most important fiscal items: general expenditure, general revenues and taxes. Hence, actually putting initiatives on the ballot leads, 
Table 2 - The General Usage of Direct Democracy

\begin{tabular}{|c|c|c|c|c|}
\hline Variables & $\begin{array}{c}\text { General } \\
\text { Expenditure }\end{array}$ & $\begin{array}{c}\text { General Revenue } \\
\text { (net of intergov. revenue) }\end{array}$ & Taxes & Charges \\
\hline Usage_dd $t-1$ & $\begin{array}{l}43.9 * \\
(26.2)\end{array}$ & $\begin{array}{l}54.2^{* *} \\
(25.2)\end{array}$ & $\begin{array}{c}40.8^{* *} \\
(20.5)\end{array}$ & $\begin{array}{c}13.3 \\
(11.0)\end{array}$ \\
\hline INCOME_PC & $\begin{array}{c}0.53^{* * *} \\
(0.11)\end{array}$ & $\begin{array}{c}0.42^{* * *} \\
(0.11)\end{array}$ & $\begin{array}{c}0.41 * * * \\
(0.10)\end{array}$ & $\begin{array}{c}0.012 \\
(0.037)\end{array}$ \\
\hline FEDERALREV & $\begin{array}{c}0.83^{* * *} \\
(0.090)\end{array}$ & $\begin{array}{c}0.23^{* *} \\
(0.11)\end{array}$ & $\begin{array}{c}0.28 * * * \\
(0.093)\end{array}$ & $\begin{array}{l}-0.048 \\
(0.033)\end{array}$ \\
\hline POPGROWTH & $\begin{array}{l}65.2^{*} \\
(34.4)\end{array}$ & $\begin{array}{c}61.0 * * \\
(26.5)\end{array}$ & $\begin{array}{c}33.5 \\
(25.2)\end{array}$ & $\begin{array}{c}27.4^{* *} \\
(11.1)\end{array}$ \\
\hline POPDENS & $\begin{array}{c}3.60 \\
(3.73)\end{array}$ & $\begin{array}{c}0.62 \\
(2.69)\end{array}$ & $\begin{array}{c}3.29 \\
(2.14)\end{array}$ & $\begin{array}{c}-2.67 * * * \\
(0.97)\end{array}$ \\
\hline INDUSTRY_POP & $\begin{array}{c}1.37 \\
(12.5)\end{array}$ & $\begin{array}{c}89.8^{* * *} \\
(22.0)\end{array}$ & $\begin{array}{c}70.5^{* * *} \\
(17.4)\end{array}$ & $\begin{array}{c}19.3^{* * *} \\
(6.60)\end{array}$ \\
\hline $\begin{array}{l}\text { State dummies } \\
\text { Year dummies }\end{array}$ & $\begin{array}{l}\text { Yes } \\
\text { Yes }\end{array}$ & $\begin{array}{l}\text { Yes } \\
\text { Yes }\end{array}$ & $\begin{array}{l}\text { Yes } \\
\text { Yes }\end{array}$ & $\begin{array}{l}\text { Yes } \\
\text { Yes }\end{array}$ \\
\hline Observations & 391 & 391 & 391 & 391 \\
\hline Number of States & 23 & 23 & 23 & 23 \\
\hline F test & 0.000 & 0.000 & 0.000 & 0.000 \\
\hline
\end{tabular}

Significance level: ${ }^{* * *} p<0.01,{ }^{* *} p<0.05{ }^{*} p<0.10$.

Note: The dependent variables are expressed in per capita current dollars. The data are pooled from 1992 to 2009 (Alaska is excluded from all regressions). Coefficients on year- and state-specific fixed effects are not reported in the table. Newey-West (1987) robust standard errors (assuming a one-lag autocorrelation structure of the error term) are in parentheses.

Source: Authors' elaborations

on average, to more spending and taxation among States permitting initiatives.

Compared to findings on the existence effects, two points should be noted. First, passing to some extent from de jure to de facto political power when qualifying the existence of initiatives with their usage, the importance of such instruments emerge in differently permitting State's political system. States like California and Oregon, where initiatives are a regular part of the political landscape, should not be treated like Illinois, Mississippi, and Wyoming, where rules nominally grant the option for using initiatives but decades pass before any measure is ever qualified. When actually used, policy tends to more closely match the preferences of the median voter and public opinion in initiative-States, leading to outcomes less fiscally conservative and more prone to government intervention into the economy (see also Smith and Tolbert 2007). Second, the usage-result suggests that the mere existence of direct democracy measures is not a sufficient condition to be more fiscally "virtuous" as a whole, i.e. to tax and spend less, because when citizens actually call for initiatives that are voted, they seem to contribute to increasing both State revenues and expenditures. 
In short, the actual implementation of direct democracy measures appears to have increased the size of the public sector and both sides of the budget during the years 1992-2009 for initiative-States. Comments on the control variables are similar to those drawn in the previous section.

\subsection{The Usage of Direct Democracy by Type}

Table 3 shows estimation results when $U s a g e \_d d_{i t-1}$ is represented by two one-year lagged dummies denoting the type of instrument used: a dummy $D$ equal to 1 if initiative is of direct type; a dummy $I$ equal to 1 if initiative is of indirect type. We also add the share of initiatives passed by type one-year lagged, i.e. the proportion of indirect initiatives passed over their total; the proportion of direct initiatives passed over their total. This specification is adopted to disentangle the impact of measures characterized by a different intensity of direct democracy involved (i.e. direct $>$ indirect) and to take into account the ex-post effect by including the voting results. The other right-hand side variables are the same as in the previous specifications.

Looking at Table 3, it is worth noting that the type of initiative used seems to matter. The usage of indirect initiatives (I) mostly contributes to reduce fiscal outcomes. Per capita general expenditures are \$102 lower when initiative-States effectively implement initiatives of $I$ type and per capita user fees and charges for services are significantly reduced (by \$33), but without affecting general revenue. On the other hand, direct initiatives (D) show positive and statistically significant coefficients on general revenues and taxes, suggesting that when the stronger the institutions of direct democracy used, broad-based taxes are being increased. In monetary terms, $D$ initiatives are likely to increase general revenues and taxes respectively of about $\$ 57$ and $\$ 52.7$ per capita.

The result achieved by the previous literature (see Matsusaka 2004 for a survey) according to which, all other things equal, initiative-States tax and spend less than non-initiative ones can be better qualified by our findings whereby, across initiative-States, this reduction-effect holds when initiatives implemented belong to the indirect type. It should be recalled that indirect initiative process requires proponents of an initiative who have gathered enough signatures to put that measure on the ballot to first bring their proposal to the legislature and see if the measure can be legislatively enacted. If the legislature and the initiative proponents come to an agreement, the legislature would enact that law. This means the indirect initiatives go through a preliminary approval of the State legislature during a regular legislative session bringing them closer to the ordinary law making and budget making process.

On the other hand, when measures are inserted on the ballot by the voters without any role of State legislature, the initiatives are of direct type and 
Table 3 - The Usage of Direct Democracy by Type

\begin{tabular}{|c|c|c|c|c|}
\hline Variables & $\begin{array}{c}\text { General } \\
\text { Expenditure }\end{array}$ & $\begin{array}{c}\text { General Revenue } \\
\text { (net of intergov. revenue) }\end{array}$ & Taxes & Charges \\
\hline \multirow[t]{2}{*}{ Dummy for usage $I_{t-1}$} & $-102 * *$ & -12.9 & 19.8 & $-32.7 * *$ \\
\hline & (43.7) & $(45.9)$ & $(40.6)$ & (13.8) \\
\hline \multirow[t]{2}{*}{ Dummy for usage $D_{t-1}$} & 43.1 & $57.0 * *$ & $52.7^{* *}$ & 4.32 \\
\hline & (33.3) & $(27.7)$ & $(22.7)$ & (12.9) \\
\hline \multirow[t]{2}{*}{ Share of I passed pas $_{t}$} & $99.5^{*}$ & -21.7 & -53.7 & $32.1^{*}$ \\
\hline & (53.4) & (61.5) & $(52.0)$ & $(17.8)$ \\
\hline \multirow[t]{2}{*}{ Share of D passed $t-1$} & -18.6 & -32.8 & -39.2 & 6.43 \\
\hline & $(41.0)$ & (33.1) & $(27.3)$ & $(13.2)$ \\
\hline \multirow[t]{2}{*}{ INCOME_PC } & $0.54 * * *$ & $0.43^{* * *}$ & $0.42 * * *$ & 0.014 \\
\hline & $(0.11)$ & $(0.12)$ & $(0.10)$ & $(0.037)$ \\
\hline \multirow[t]{2}{*}{ FEDERALREV } & $0.82 * * *$ & $0.23 * *$ & $0.28 * * *$ & -0.050 \\
\hline & $(0.090)$ & $(0.11)$ & $(0.094)$ & (0.033) \\
\hline \multirow[t]{2}{*}{ POPGROWTH } & $58.2^{*}$ & $61.9 * *$ & 36.1 & $25.8^{* *}$ \\
\hline & (33.7) & $(27.1)$ & $(25.3)$ & (11.3) \\
\hline \multirow[t]{2}{*}{ POPDENS } & 3.27 & 0.68 & 3.47 & $-2.79 * * *$ \\
\hline & (3.68) & $(2.65)$ & $(2.13)$ & $(0.98)$ \\
\hline \multirow[t]{2}{*}{ INDUSTRY_POP } & 5.60 & $90.5^{* * *}$ & $70.2 * * *$ & $20.3 * * *$ \\
\hline & (13.0) & $(21.7)$ & (17.0) & $(6.77)$ \\
\hline State dummies & Yes & Yes & Yes & Yes \\
\hline Year dummies & Yes & Yes & Yes & Yes \\
\hline Observations & 391 & 391 & 391 & 391 \\
\hline Number of States & 23 & 23 & 23 & 23 \\
\hline $\mathrm{F}$ test & 0.000 & 0.000 & 0.000 & 0.000 \\
\hline
\end{tabular}

Significance level: ${ }^{* * *} p<0.01,{ }^{* *} p<0.05{ }^{*} p<0.10$.

The dependent variables are expressed in per capita current dollars. The data are pooled from 1992 to 2009 (Alaska is excluded from all regressions). Coefficients on year- and state-specific fixed effects are not reported in the table. Newey-West (1987) robust standard errors (assuming a one-lag autocorrelation structure of the error term) are in parentheses.

Source: Authors' elaborations 
voters basically circumvent the legislature by expanding general taxation, possibly to serve additional expenditure (although the effect on this variable is not statistically significant).

One cannot conclude that initiative-States always spend and tax more when the initiative process is effectively implemented as it depends on which type of initiative is at work: only the usage of direct initiatives $(D)$ seems to produce an expansionary fiscal effect (at least on the revenue side), while the usage of indirect initiatives $(I)$ tends to have a constraining fiscal effect (mostly on the expenditure side).

\subsection{The Usage of Direct Democracy by Topic}

The third part of the analysis tries to add the importance of considering direct democracy practice by topic in order to capture more details on what has been happening. In this respect, we cover the gap in the literature where several studies were limited in investigating the policy effect of initiatives in only one or two policy areas, while many improved ways should be adopted to measure the extent of the initiative use (for a review see Bowler and Donovan 2004).

The topic of each initiative identifies its scope and purpose. As already discussed, topics can vary widely (e.g., taxes, spending, bonds, education, health, regulation, business, constitutional issues, environment, civil rights, government administration, etc.).

Keeping this in mind, we re-estimate equation (2) for the same initiativeStates sub-sample after grouping all topics observed on the ballot into six categories selected as the most frequently at stake from 1992 to 2009. Six dummies variables are built and included in one-year lagged values to represent $U$ sage_d $d_{i t-1}$ in equation (2). More precisely, we consider: a) Bond and State Spending (i.e. the dummy is equal to 1 when the initiative implemented contains propositions concerning bond or State spending; the same logic is adopted to define the other five topic-dummies); b) Education and Health; c) Taxes and Revenues; d) Regulation and Environment; e) Election and Administration of government; f) Other as a residual category including all other possible topics put on the ballot.

Figure A.2 (see the Appendix) shows the percentage composition of the six topics in each initiative-States over the period 1992-2009. The first five categories represent more than $80 \%$ of the total, and within each group direct initiatives $(D)$ are more than indirect initiatives $(I)$, with the exception of Bond and State Spending. In this part of the analysis, we deliberately neglect the type of initiative (i.e. $D$ and $I$ ) in order to isolate the effects of the different propositions content put on the ballot.

Analyzing the single initiatives' content to separate those expected to increase revenue/expenditure from those expected to have a contrary effect is a lengthily and not obvious task. For typical propositions related to, for 
example, Civil rights, even after reading the actual contents of the propositions, in the short term we do not expect a clear impact on fiscal variables. But also for initiatives that are more directly connected to tax and spending decisions (such as propositions referred to the category Taxes $\mathcal{E}$ Revenues), topic categories are not per se necessarily related to a particular directional outcome on spending and revenue variables. The analysis actually reveals patterns one would not necessarily expect.

Estimation results on the usage of direct democracy by topics are reported in Table 4. The initiatives on Taxes and Revenues concern issues related to increasing specific taxes and dedicating them to specific expenditures, as well as the more general issue of reducing taxes (albeit in the time period analyzed in this paper the latter category is more frequent). These occurrences do not have a significant impact on any of the more general fiscal items.

The Education and Health topic seems to be relevant for charges. Indeed, its coefficient is positive and statistically significant suggesting that questions usually referred to organizational, administrative and managerial aspects of those services may favor increases in revenues coming from the public for performance of such services. As a matter of fact, the two largest revenue sources classified as charges were tolls from roads and tuition payments for education.

A persistent positive effect on fiscal variables comes from topics on Election and Administration of Government whose questions seem to favor an increase in general revenues, taxes, and general expenditures. This is likely to occur when propositions on the ballot concern, for example, legislator salaries, extension of legislative term limits and other similar subjects also referred to the authority of counties, cities, towns and villages, and more generally involving constitutional and institutional relations among different entities of the public sector.

Finally, Bond and State Spending topics do not have statistically significant impact (at least at 10\%) on fiscal outcomes. Nevertheless, they basically hold positive coefficients for spending items and negative ones for revenue items.

In general, questions on State Spending are usually put on the ballot to limit the growth of expenditures (i.e. TELs) with a direct effect on the tax side of the budget as fewer resources can be probably needed to finance a lower level of spending. In turn, Bond propositions usually contribute to increase spending. At the same time, voters might be willing to propose bond measures as an alternative financing mechanism with respect to taxation (although this view could end up being a bit myopic as it does not consider interests' payment that must be paid on bonds).

In general, these results uncover correlations in the data, although they may not be considered proof of causality. They should be considered exploratory of the fact that, even knowing in more detail the contents of the initiative, does not necessary imply clear-cut fiscal effects. 
Table 4 - The Usage of Direct Democracy by Topic

\begin{tabular}{|c|c|c|c|c|}
\hline Variables & $\begin{array}{c}\text { General } \\
\text { Expenditure }\end{array}$ & $\begin{array}{c}\text { General Revenue } \\
\text { (net of intergov. revenue) }\end{array}$ & Taxes & Charges \\
\hline \multirow[t]{2}{*}{ Bond \& Spending t -1} & 14.1 & -23.8 & -35.2 & 11.4 \\
\hline & $(40.0)$ & $(36.2)$ & (30.8) & $(11.4)$ \\
\hline \multirow[t]{2}{*}{ Education \& Health $h_{t-1}$} & 9.96 & -2.49 & -19.3 & $16.8^{*}$ \\
\hline & (31.9) & $(26.3)$ & $(23.2)$ & $(10.2)$ \\
\hline \multirow[t]{2}{*}{ Taxes \& Revenuest-1 } & -39.0 & 23.9 & 13.8 & 10.1 \\
\hline & (29.7) & $(26.8)$ & $(22.0)$ & $(10.0)$ \\
\hline \multirow[t]{2}{*}{ Regulation \& Environment ${ }_{t-1}$} & -11.1 & $-49.1 *$ & -37.8 & -11.4 \\
\hline & (33.0) & $(25.9)$ & $(23.5)$ & (9.97) \\
\hline \multirow[t]{2}{*}{ Election \& Admin of Govt-1 } & $63.1 * *$ & $53.8 * *$ & $46.0 * *$ & 7.76 \\
\hline & $(26.9)$ & $(25.3)$ & $(22.0)$ & $(9.33)$ \\
\hline \multirow[t]{2}{*}{ Other $_{t-1}$} & -37.3 & 3.70 & 25.8 & $-22.1 * *$ \\
\hline & $(30.6)$ & (31.9) & $(27.6)$ & $(10.7)$ \\
\hline \multirow[t]{2}{*}{ INCOME_PC } & $0.53 * * *$ & $0.40 * * *$ & $0.39 * * *$ & 0.012 \\
\hline & $(0.11)$ & $(0.11)$ & $(0.098)$ & $(0.037)$ \\
\hline \multirow[t]{2}{*}{ FEDERALREV } & $0.83^{* * *}$ & $0.24 * *$ & $0.29 * * *$ & -0.045 \\
\hline & $(0.096)$ & $(0.11)$ & $(0.095)$ & $(0.033)$ \\
\hline \multirow[t]{2}{*}{ POPGROWTH } & $71.5^{* *}$ & $68.0 * * *$ & 37.8 & $30.1 * * *$ \\
\hline & (33.4) & $(26.0)$ & $(24.4)$ & (10.9) \\
\hline \multirow[t]{2}{*}{ POPDENS } & 3.19 & 0.079 & 2.62 & $-2.54 * * *$ \\
\hline & (3.58) & $(2.66)$ & $(2.12)$ & $(0.94)$ \\
\hline \multirow[t]{2}{*}{ INDUSTRY_POP } & -1.16 & $87.1^{* * *}$ & $69.8^{* * *}$ & $17.3 * * *$ \\
\hline & $(12.6)$ & $(21.4)$ & $(17.1)$ & $(6.44)$ \\
\hline State dummies & Yes & Yes & Yes & Yes \\
\hline Year dummies & Yes & Yes & Yes & Yes \\
\hline Observations & 391 & 391 & 391 & 391 \\
\hline Number of States & 23 & 23 & 23 & 23 \\
\hline $\mathrm{F}$ test & 0.000 & 0.000 & 0.000 & 0.000 \\
\hline
\end{tabular}

Significance level: ${ }^{* * *} p<0.01,{ }^{* *} p<0.05{ }^{*} p<0.10$.

The dependent variables are expressed in per capita current dollars. The data are pooled from 1992 to 2009 (Alaska is excluded from all regressions). Coefficients on year- and state-specific fixed effects are not reported in the table. Each topic is expressed through a dummy variable in one-year lagged values. Newey-West (1987) robust standard errors (assuming a one-lag autocorrelation structure of the error term) are in parentheses. Source: Authors' elaborations 


\subsection{The Effects of Using Direct Democracy on State and Local Fiscal Outcomes}

Overall, the results suggest that there may be a different pattern of effects when it comes to the variation in the actual use of initiatives rather than in the institutional rules related to direct democracy across States. The latter may not provide a fully comprehensive measure of direct democracy (as suggested also by Bowler and Donovan 2004, and Asatryan et al. 2013).

Voters usually use initiatives when their representatives' preferences are diverging too much from their own preferences. When indirect initiatives are put on the ballot, the proposals they contain have already been reined in by the legislature and administration officials. In some way, this leads to a reduction of State general expenditure and a shift towards lowering the direct burden of service-based tariffs and charges. But when direct initiatives are held, voters circumvent legislature's preferences and they tend to expand general taxation related to everyone, possibly in the attempt to serve additional expenditure, closer to their own control, i.e. at the local level.

This explanation is confirmed by looking into the effects of initiative usage on wider set of fiscal variables including consolidated expenditure and revenue, i.e. the sum of State and local governments. ${ }^{25}$ Indeed, as shown in Table 5, when all local expenditures are considered in addition to those provided for by State-level transfers, direct initiatives yield a significant increase in general expenditure (column 3).

In addition, Table 5 provides a robustness check to the previous analyses in Tables 4-6. The first two columns refer to the general usage model; the third and fourth to the usage of direct democracy by type; the last two report findings for the usage of direct democracy by topic. We confirm evidence of a positive and statistically significant (even at 10\%) correlation between the general usage of initiatives and both combined State and local government general revenue and expenditure (reinforcing the results shown in Table 2). In monetary terms, $U$ sage_d $d d_{i t-1}$ increases aggregated revenues and spending respectively of about $\$ 75$ and $\$ 70$ per capita.

Passing to usage by initiative-type, robust results emerge in the case of $D$ initiatives with positive and significant coefficients for both the dependent variables (as in Table 3). In the case of indirect initiatives, however, no significant effects emerge on consolidated fiscal items. The same holds in the case of the usage by initiative-topic, with the exception of propositions on Election and Administration of Government confirming a persistent positive effect on State and local expenditure as that found in Table 4.

${ }^{25}$ Unfortunately, the increase in the spending and revenue definitions comes at the cost of losing some years (i.e. 2001 and 2003), and then observations, during which data on State and local are not available from the official source (US Bureau of Census). 
Table 5 - The Usage of Direct Democracy with State and Local Consolidated Fiscal Items

\begin{tabular}{|c|c|c|c|c|c|c|}
\hline Variables & $\begin{array}{c}\text { General } \\
\text { Expenditure } \\
\text { (State \& Local) }\end{array}$ & $\begin{array}{c}\text { General } \\
\text { Revenue } \\
\text { (State \& } \\
\text { Local) } \\
\end{array}$ & $\begin{array}{c}\text { General } \\
\text { Expenditure } \\
\text { (State \& Local) }\end{array}$ & $\begin{array}{c}\text { General } \\
\text { Revenue } \\
\text { (State \& } \\
\text { Local) }\end{array}$ & $\begin{array}{c}\text { General } \\
\text { Expenditure } \\
\text { (State \& Local) }\end{array}$ & $\begin{array}{c}\text { General } \\
\text { Revenue } \\
\text { (State \& } \\
\text { Local) } \\
\end{array}$ \\
\hline \multirow[t]{2}{*}{ Usage_dd $d_{t-1}$} & $70.1^{*}$ & $75.1^{*}$ & --- & --- & --- & --- \\
\hline & (38.9) & (39.3) & --- & --- & --- & --- \\
\hline \multirow[t]{2}{*}{ Dummy for usage $I_{t-1}$} & --- & --- & -45.7 & -26.2 & --- & --- \\
\hline & --- & --- & $(73.6)$ & $(60.3)$ & --- & --- \\
\hline \multirow[t]{2}{*}{ Dummy for usage $D_{t-1}$} & --- & --- & $100 * *$ & $102 * *$ & --- & --- \\
\hline & --- & --- & $(47.1)$ & $(43.5)$ & --- & --- \\
\hline \multirow[t]{2}{*}{ Share of I passed $d_{t-1}$} & --- & --- & -9.80 & -62.4 & --- & --- \\
\hline & --- & --- & (92.5) & (76.9) & --- & --- \\
\hline \multirow[t]{2}{*}{ Share of D passed ${ }_{t-1}$} & --- & --- & -55.7 & -60.4 & --- & --- \\
\hline & --- & --- & $(67.6)$ & $(58.0)$ & --- & --- \\
\hline \multirow[t]{2}{*}{ Bond \& Spending ${ }_{t-1}$} & --- & --- & --- & --- & 10.4 & -76.0 \\
\hline & --- & --- & --- & --- & (55.6) & (53.9) \\
\hline \multirow[t]{2}{*}{ Education \& Health $t_{t-1}$} & --- & --- & --- & --- & 55.2 & 24.0 \\
\hline & --- & --- & --- & --- & (48.9) & $(45.7)$ \\
\hline \multirow[t]{2}{*}{ Taxes \& Revenuest-1 } & --- & --- & --- & --- & -34.7 & 53.6 \\
\hline & --- & --- & --- & --- & (43.7) & (37.9) \\
\hline \multirow[t]{2}{*}{$\begin{array}{l}\text { Regulation \& } \\
\text { Environment } t_{t-1}\end{array}$} & --- & -- & --- & --- & -27.0 & -27.6 \\
\hline & --- & --- & --- & --- & $(51.8)$ & $(40.7)$ \\
\hline \multirow[t]{2}{*}{ Election \& Admin of Gov $v_{t-1}$} & --- & --- & --- & --- & $90.2^{* *}$ & 59.4 \\
\hline & --- & --- & --- & --- & $(45.2)$ & $(37.3)$ \\
\hline \multirow[t]{2}{*}{ other $_{t-1}$} & --- & --- & --- & --- & -29.4 & -8.17 \\
\hline & --- & --- & --- & --- & $(52.4)$ & $(51.8)$ \\
\hline State dummies & Yes & Yes & Yes & Yes & Yes & Yes \\
\hline Year dummies & Yes & Yes & Yes & Yes & Yes & Yes \\
\hline Observations & 345 & 345 & 345 & 345 & 345 & 345 \\
\hline Number of States & 23 & 23 & 23 & 23 & 23 & 23 \\
\hline F test & 0.000 & 0.000 & 0.000 & 0.000 & 0.000 & 0.000 \\
\hline
\end{tabular}

Significance level: ${ }^{* *} p<0.01,{ }^{* *} p<0.05{ }^{*} p<0.10$.

The dependent variables are expressed in per capita current dollars. The data are pooled from 1992 to 2009 (Alaska is excluded from all regressions); 2001 and 2003 data are missing. Coefficients on year- and statespecific fixed effects as well as those on control variables are not reported in the table. Newey-West (1987) robust standard errors (assuming a one-lag autocorrelation structure of the error term) are in parentheses.

Source: Authors' elaborations 


\section{Concluding Remarks}

This paper is a first attempt to analyze the effect of direct democracy on fiscal outcomes in the US focusing on the actual practice of initiatives rather than on the mere availability of the process. Indeed, previous studies on direct democracy traditionally look into the institutional features characterizing the existence of the initiative process but neglecting whether they are actually put on the ballot and voted.

The existence-decision, which has been taken long ago in the US, is basically a top-down handout, while the usage-decision mostly captures a bottom-up will. These different approaches are likely to give rise to different results between the possibility and the actual usage of direct democracy, as emerges from our work. Moreover, several features of direct democracy (e.g., the type of instrument used; the result of the voting process; the topics of concern) are taken into account as well as a more recent time span with respect to previous studies.

Over years from 1992 to 2009 we observe that States permitting initiatives are likely to spend less and tax less than non-initiative ones. But when the actual usage of the initiative process is analyzed, by focusing on the subsample of initiative-States only, a different picture emerges. In particular, we find that actually putting initiatives on the ballot tends to be associated with higher State government general expenditure and revenue. When moving from more aggregate measures for usage to specific types of initiatives implemented, manifold results can be obtained across specifications. Indeed, while the use of indirect initiatives seems to be more effective in reducing fiscal variables mainly on the expenditure side, the adoption of direct initiatives tends to be associated with increases in the tax categories. The different intensity degree of direct democracy involved by the two instruments is reflected in their differential impacts on fiscal policy. Finally, the representation of direct democracy practice based on the topics put on the ballots helps to provide some hints for further research.

All in all, empirical studies - especially on a single country - when using an index-variable which captures only one dimension of direct democracy phenomenon may produce incomplete results. Our work tries to describe the importance, other things equal, of a more specific representation and estimations based on multiple vision of direct democracy practice keeping, however, in mind that voter initiatives make a difference at the margins, but the prime movers of fiscal outcomes are other factors. Beyond this, much remains to be learned about the impact of direct democracy institutions. 


\section{References}

Acemoglu, D., Robinson, J.A., 2006. Economic Origins of Dictatorship and Democracy. Cambridge University Press, New York.

Acemoglu, D., Robinson, J.A., 2008. Persistence of Power, Elites and Institutions. American Economic Review 98, 267-293. doi:/10.1257/aer.98.1.267

Alt, J., Lassen, D., 2003. The Political Economy of Institutions and Corruption in American States. Journal of Theoretical Politics 5, 341-365. doi:/10.1177/0951692803015003006

Asatryan, Z., Baskaran, T., Grigoriadis, T., Heinemann, F., 2013. Direct democracy and local public finances under cooperative federalism, ZEW Discussion Paper No. 13-038.

Blomberg, S., Brock, G., Hess, D., Weerapana, A., 2004. The Impact of Voter Initiatives on Economic Activity. European Journal of Political Economy 1, 207-226. doi:/10.1016/j.ejpoleco.2003.02.003

Blume, L., Müller, J., Voigt, S., 2009. The Economic Effects of Direct Democracy - a First Global Assessment. Public Choice 140, 431-461. doi:/10.1007/s11127-009-9429-8

Bohn, H., Inman, R.P., 1996. Balanced Budget Rules and Public Deficits: Evidence from U.S. States. Carnegie-Rochester Conference Series on Public Policy 45, 13-76. doi:/10.1016/S0167-2231(96)00017-6

Bowler, S., Donovan, T., 2002. Democracy, Institutions and Attitudes about Citizen Influence on Government. British Journal of Political Science 32, 371-390. doi:/10.1017/S0007123402000157

Bowler, S., Donovan, T., 2004. Measuring the Effect of Direct Democracy on State Policy. State Politics \& Policy Quarterly 4, 345-363. doi:/10.1177/153244000400400305

Broder, D.S., 2000. Democracy Derailed: Initiative Campaigns and the Power of Money. New York: Harcourt Inc.

Butler, D., Ranney, A., 1994. Referendums Around the World. The Growing Use of Direct Democracy. Washington: The AEI Press.

Camobreco, J.F., 1998. Preferences, Fiscal Policies, and the Initiative Process. Journal of Politics 60, 891-829. doi:/10.2307/2647650

Cheibub, J.A., 2006. Presidentialism, Electoral Identifiability, and Budget Balances in Democratic Systems, American Political Science Review 100, 353-368. doi:/10.1017/S000305540606223X 
Dalton, R., 2008. Direct Democracy Good Governance: Does It Matter? In: Sh. Bowler S. and Glazer A. (Eds.), Direct Democracy's Impact on American Political Institutions. Palgrave Macmillan, Basingstoke.

Feld, L.P., Kirchgassner, G., 1999. Public Debt and Budgetary Procedures: Top Down or Bottom up? Some Evidence from Swiss Municipalities. In: Fiscal Institutions and Fiscal Performance.

Feld, L.P., Kirchgassner, G., 2000) Direct Democracy, Political Culture, and the Outcome of Economic Policy: A Report on the Swiss Experience. European Journal of Political Economy 16, 287 - 306. doi:/10.1016/S01762680(00)00003-3

Feld, L.P., Kirchgassner, G., 2001. Does Direct Democracy Reduce Public Debt? Evidence from Swiss Municipalities. Public Choice 109, 181 - 213.

Feld, L.P., Matsusaka, J.G., 2003. Budget Referendums and Government Spending: Evidence from Swiss Cantons. Journal of Public Economics 87, 2703 - 2724. doi:/10.1016/S0047-2727(02)00140-8

Funk, P., Gathmann, C., 2011. Does Direct Democracy Reduce the Size of Government? New Evidence from Historical Data, 1890 - 2000. Economic Journal 121, 1252 - 1280. doi:/10.1111/j.1468-0297.2011.02451.x

Galletta, S., Jametti, M., 2012. How to Tame two Leviathans? Revisiting the Effect of Direct Democracy on Local Public Expenditure. CESifo Working Paper No. 3982.

Gerber, E.R., 1996. Legislative Response to the Threat of Popular Initiatives. American Journal of Political Science 40, 99 - 128. doi:/10.2307/2111696

Gerber, E.R., 1999. The Populist Paradox: Interest Group Influence and the Promise of Direct Legislation. Princeton University Press, Princeton.

Gunn, P., 1981. Initiatives and Referendums: Direct Democracy and Minority Interests. Urban Law Annual 22, 135-159.

Hajnal, Z., Gerber, E.R., Louch, H., 2002. Minorities and Direct Legislation: Evidence from California Ballot Proposition Elections. Journal of Politics 64, 154-177. doi:/10.1111/1468-2508.00122

Hale, G.E., Palley, M.L., 1981. The Politics of Federal Grants. Washington D.C.: Congressional Quarterly Press.

Hessami, Z., Thum, M., Übelmesser, S., 2012. A Political Economy Explanation for In-kind Redistribution: The Interplay of Corruption and Democracy. Working paper n. 25. University of Konstanz. 
Hinnerich, B.T., Pettersson-Lidbom, P., 2010. Democracy, redistribution, and political participation: evidence from Sweden 1919-1938, Working Paper Stockholm University.

Hobolt, S.B., 2006. Direct Democracy and European Integration. Journal of European Public Policy 13, 153-166. doi:/10.1080/13501760500380825

Iversen, T., Soskice, D., 2006. Electoral Institutions and the Politics of Coalitions: Why Some Democracies Redistribute More Than Others. American Political Science Review 2, 165-181.

Krol, R., 2007. The Role of Fiscal and Political Institutions in Limiting the Size of State Government. Cato Journal 27, 431-445.

Lascher, E.L., Hagen, M., Rochlin, S., 1996. Gun Behind the Door? Ballot Initiatives, State Politics, and Public Opinion. Journal of Politics 58, 760775. doi:/10.2307/2960443

Lupia, A., Matsusaka, J., 2004. Direct Democracy: New Approaches to Old Questions. Annual Review of Political Science 7, 463-482. doi:/10.1146/annurev.polisci.7.012003.104730

Magleby, D.B., 1984. Direct Legislation: Voting on Ballot Propositions in the United States. Baltimore: Johns Hopkins University Press.

Marschall, M.J, Ruhil, A., 2005. Fiscal Effects of the Voter Initiative Reconsidered: Addressing Endogeneity. State Politics and Policy Quarterly 5, 327355. doi:/10.1177/153244000500500401

Matsusaka, J.G., 1995. Fiscal Effects of the Voter Initiative: Evidence from the Last 30 Years. Journal of Political Economy 103, 587 - 623. doi:/10.1086/261996

Matsusaka, J.G., 2000. Fiscal Effects of the Voter Initiative in the First Half of the 20th Century. Journal of Law and Economics 43, 619 - 648. doi:/10.1086/467467

Matsusaka J.G., 2003. The initiative and referendum in American cities: Basic patterns. In M.D. Waters (Ed.), The initiative and referendum almanac: A comprehensive reference guide to citizen lawmaking around the world. Carolina Academic Press.

Matsusaka J.G., 2004. For the Many or the Few: The Initiative Process, Public Policy, and American Democracy. Chicago, University Chicago Press. doi:/10.7208/chicago/9780226510873.001.0001

Matsusaka, J.G., 2005. Direct Democracy Works. Journal of Economic Perspective 19, 185 - 206. doi:/10.1257/0895330054048713 
Matsusaka, J.G., 2012. Disentangling the Direct and Indirect Effects of the Initiative Process. Mimeo.

Matsusaka, J.G, McCarty, N-M., 2001. Political Resource Allocation: Benefits and Costs of Voter Initiatives. Journal of Law, Economics, and Organization 17, 413 - 448. doi:/10.1093/jleo/17.2.413

Newey, W.K., West, K. D., 1987. A simple, positive semi-definite, heteroskedasticity and autocorrelation consistent covariance matrix. Econometrica 55, 703-708. doi:/10.2307/1913610

Olson, J.M., 1972. Limitations and Litigation Approaches: The Local Power of Referendum in Federal and State Courts-A Michigan Model, Journal of Urban Law 50.

Persson, T., Tabellini, G., 2004. Constitutional Rules and Fiscal Policy Outcomes. The American Economic Review 94, 25-45. doi:/10.1257/000282804322970689

Pettersson-Lidbom, P., Tyrefors, B., 2007. The Policy Consequences of Direct versus Representative Democracy: A Regression-Discontinuity Approach. Working Paper Stockholm School of Economics.

Romer, T., Rosenthal, H., 1979. Bureaucrats versus Voters: On the Political Economy of Resource Allocation by Direct Democracy. Quarterly Journal of Economics 93, 563 - 587. doi:/10.2307/1884470

Sears, D. O., Citrin, J., 1985. Tax Revolt: Something for Nothing in California. Harvard University Press, Cambridge.

Smith, D.A., 2001. Special Interests and Direct Democracy: An Historical Glance. D. Waters (Ed.), In The Battle of Citizens Lawmaking. Carolina Academic Press, Durham.

Smith, D., Tolbert, C., 2004. Educated by Initiative. University of Michigan Press, Ann Arbor.

Smith, D., Tolbert, C., 2007. The Instrumental and Educative Effects of Ballot Measures: Research on Direct Democracy in the American States. State Politics and Policy Quarterly 7, 416-445. doi:/10.1177/153244000700700404

Stimson, JA., 1999. Public Opinion in America: Moods, Cycles, and Swings. Westview Press, Boulder.

Tolbert, C., Grummel, J., Smith, D., 2001. The Effects of Ballot Initiatives on Voter Turnout in the American States. American Politics Review 29, 625648. doi:/10.1177/1532673X01029006005 
Voigt, S., 2011. Positive Constitutional Economics II - a Survey of Recent Developments. Public Choice 146, 205-256. doi:/10.1007/s11127-010-96381

Zax, J.S., 1989. Initiatives and Government Expenditures. Public Choice 63, 267-277. doi:/10.1007/BF00138166

Zimmerman, J.F., 1999. The Initiative: Citizen Law-Making. Praeger, Westport. 


\section{Appendix}

Table A.1 - Summary Statistics for Explanatory and Control Variables

\begin{tabular}{|c|c|c|c|c|}
\hline Variables & Mean & Std. Dev. & Min & Max \\
\hline & \multicolumn{4}{|c|}{ All States } \\
\hline Income per capita (current \$) & 3,139 & 788 & 1,745 & 6,736 \\
\hline Population density (per square mile) & 151 & 188 & 5 & 968 \\
\hline Annual growth rate of population (\%) & 1.09 & 0.91 & -5.99 & 6.24 \\
\hline $\begin{array}{l}\text { Population with total full- and part-time employment by industry (\% of total } \\
\text { population) }\end{array}$ & 58.60 & 5.01 & 43.70 & 74.73 \\
\hline Intergovernmental revenue per capita (current \$) & 1,141 & 490 & 405 & 4,165 \\
\hline \multirow[t]{2}{*}{ Existence_dd } & 0.50 & 0.50 & 0 & 1 \\
\hline & \multicolumn{4}{|c|}{ Initiative-States } \\
\hline Income per capita (current \$) & 3,142 & 787 & 1,745 & 6,736 \\
\hline Population density (per square mile) & 93 & 127 & 5 & 596 \\
\hline Annual growth rate of population (\%) & 1.27 & 1.08 & -0.54 & 6.24 \\
\hline $\begin{array}{l}\text { Population with total full- and part-time employment by industry (\% of total } \\
\text { population) }\end{array}$ & 59.30 & 5.24 & 47.02 & 74.73 \\
\hline Intergovernmental revenue per capita (current $\$$ ) & 690 & 292 & 240 & 1,932 \\
\hline \multicolumn{5}{|l|}{ Usage_dd:* } \\
\hline Dummy for usage initiatives & 0.50 & 0.50 & 0 & 1 \\
\hline Dummy for usage direct initiatives (D) & 0.44 & 0.50 & 0 & 1 \\
\hline Dummy for usage indirect initiatives (I) & 0.25 & 0.43 & 0 & 1 \\
\hline Share of direct initiatives passed over the total (DP/D) & 0.22 & 0.35 & 0 & 1 \\
\hline Share of indirect initiatives passed over the total (IP/I) & 0.17 & 0.34 & 0 & 1 \\
\hline Dummy for usage topic: Bond \& State spending & 0.12 & 0.33 & 0 & 1 \\
\hline Dummy for usage topic: Taxes \& Revenues & 0.25 & 0.43 & 0 & 1 \\
\hline Dummy for usage topic: Education \& Health & 0.20 & 0.40 & 0 & 1 \\
\hline Dummy for usage topic: Regulation \& Environment & 0.28 & 0.45 & 0 & 1 \\
\hline Dummy for usage topic: Election \& Admin of Gov & 0.30 & 0.46 & 0 & 1 \\
\hline Dummy for usage topic: Other & 0.25 & 0.43 & 0 & 1 \\
\hline
\end{tabular}

Each row reports summary statistics over the period 1992-2009. Alaska is excluded from both groups (i.e. all States and initiative-States). All variables belonging to Usage_dd are included in one-year lagged values in equation (2).

Source: Authors' elaborations 
Table A.2 - Summary Statistics for the Dependent Variables (per capita current dollars)

\begin{tabular}{lcccc|cccc}
\hline \hline Variables & Mean & Std. Dev. & Min & Max & Mean & Std. Dev. & Min & Max \\
\hline \multirow{3}{*}{ General revenue* } & 2,632 & 850 & 1,224 & 6,618 & 2,513 & 763 & 1,224 & 6,618 \\
Taxes & 1,893 & 601 & 713 & 4,931 & 1,823 & 542 & 793 & 4,931 \\
Charges & 738 & 330 & 196 & 2,601 & 690 & 292 & 240 & 1,932 \\
General Expenditure & 4,202 & 1,348 & 1,908 & 9,963 & 4,056 & 1,263 & 1,995 & 9,963 \\
\hline \hline
\end{tabular}

Each row reports summary statistics calculated over the period 1992-2009. Alaska is excluded from both groups (i.e. all States and initiative-States). ${ }^{*}$ General revenue is net of intergovernmental revenue.

Source: Authors' elaborations

Figure A.1 - Number of all Initiatives by State (1992-2009)

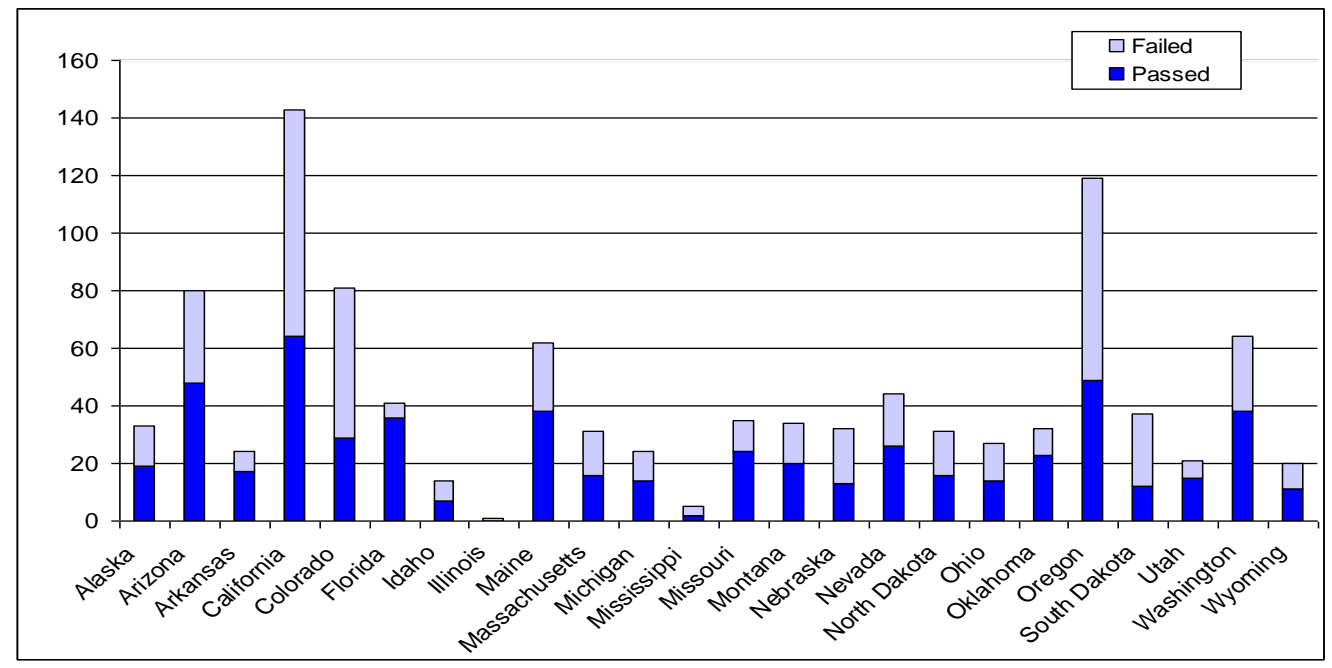

Source: Authors' elaborations 
Figure A.2 - State-by-State Percentage Composition of the Selected Topics put on the Ballot (1992-2009)

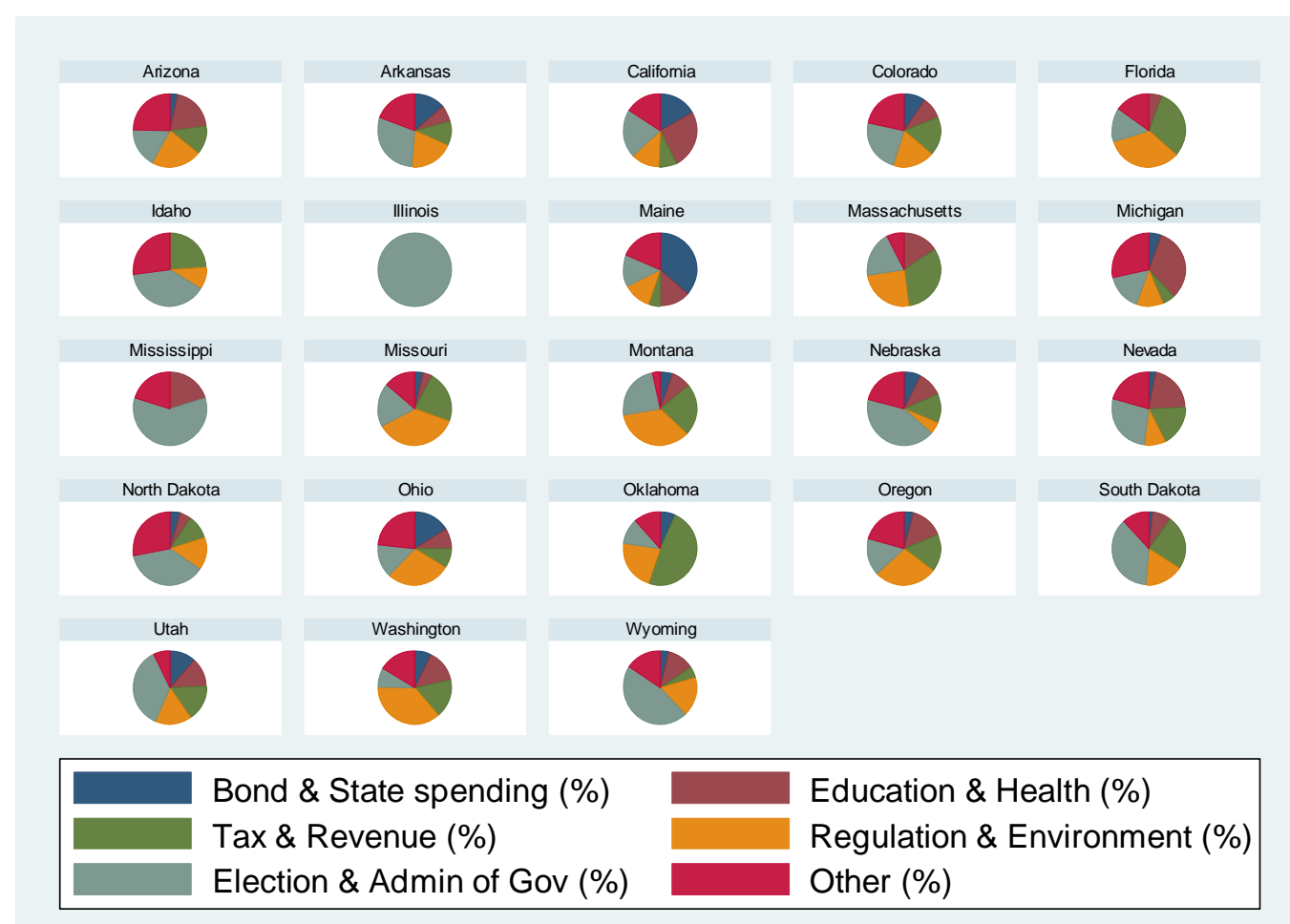

We do not report the topic composition for Alaska as it is excluded from our empirical analysis. Source: Authors' elaborations 